medRxiv preprint doi: https://doi.org/10.1101/2021.03.04.21252895; this version posted May 27, 2021. The copyright holder for this preprint (which was not certified by peer review) is the author/funder, who has granted medRxiv a license to display the preprint in perpetuity.

\title{
Evaluation of Junior Doctors' Knowledge of Corneal Donation and the New Opt-Out System in England
}

Bhavesh Gopal ${ }^{1}$, Owuraku Asiedu Titi-Lartey ${ }^{2}$, Princeton Fernandes ${ }^{3}$, Nur-Emel Noubani ${ }^{1}$, Elizabeth Blatherwick ${ }^{4}$, Dalia G. Said, ${ }^{5,6}$ Harminder S. Dua, ${ }^{5,6}$ Darren Shu Jeng Ting ${ }^{5,6}$

Collaborators: Rachel Byrne, Eleanor Green, Laura Sandland-Taylor, Laura Weir, Shahid Mohammed, Basal Atwi, Yara Hreish, Zara Faizi, Natalie Mok, Thomas Poundall, Sahana Bala, Sudha Bhagwansingh Hayne, Mohamad Ali Mortada

${ }^{1}$ Pilgrim Hospital, Lincolnshire, UK.

${ }^{2}$ Lincoln County Hospital, Lincolnshire, UK.

${ }^{3}$ Hull Royal Infirmary, Hull, UK.

${ }^{4}$ Nottingham Tissue and Eye Donation Partners, Queen's Medical Centre, Nottingham, UK.

${ }^{5}$ Department of Ophthalmology, Queen's Medical Centre, Nottingham, UK.

${ }^{6}$ Academic Ophthalmology, Division of Clinical Neuroscience, School of Medicine, University of Nottingham, Nottingham, UK.

Corresponding author: Dr. Darren S. J. Ting

Corresponding address: Academic Ophthalmology, Division of Clinical Neuroscience, School of Medicine, University of Nottingham, Nottingham, NG7 2RD, UK.

Email: ting.darren@gmail.com

Funding / support: D.S.J.T. acknowledges support from the Medical Research Council / Fight for Sight Clinical Research Fellowship (MR/T001674/1), and the Fight for Sight / John Lee, Royal College of Ophthalmologists Primer Fellowship (24CO4).

Conflict of interest: None

Key words: Corneal donation; Eye donation; Junior doctors; Opt-out system; Organ NOTE: This preprint reports new research that has not been certified by peer review and should not be used to guide clinical practice. donation; Presumed consent 
medRxiv preprint doi: https://doi.org/10.1101/2021.03.04.21252895; this version posted May 27 , 2021. The copyright holder for this preprint (which was not certified by peer review) is the author/funder, who has granted medRxiv a license to display the preprint in perpetuity.

\section{INTRODUCTION}

Corneal opacity represents the $5^{\text {th }}$ leading cause of blindness and visual impairment globally, affecting around 6 million of the population. ${ }^{1}$ Corneal transplantation serves as the mainstay of treatment in restoring vision in patients affected by corneal opacity. ${ }^{2}$ It is the most commonly performed transplantation worldwide, though the success has been persistently challenged by the global shortage of donor cornea. ${ }^{2}$

To date, a wide range of initiatives and advancement, including public campaigns to increase awareness, introduction of telephone consent, refinement in the donationtransplantation pathway and improvement in surgical techniques, ${ }^{3-6}$ have been implemented to improve corneal donation and utility of donor corneal tissues. On $20^{\text {th }}$ May 2020, England has implemented an opt-out system, also known as the Max and Keira's Law, with an aim to improve the rate of organ/tissue donation, joining countries such as Spain, France and Italy, and many others. Under the new, soft opt-out system, all adults in England are assumed to be willing organ/tissue donors unless they have registered their intent otherwise. However, the process of eye donation remains largely unchanged as consent from the family members is still required before retrieval can proceed.

Junior doctors at frontline services, particularly those who work in intensive care, oncology and palliative care units, may serve as valuable members to the multi-disciplinary team in contributing to the process of organ/tissue donations. Nonetheless, the knowledge of corneal donation and the new opt-out system among junior doctors in the UK has not been explored. Our study aimed to evaluate the knowledge of corneal donation and the opt-out system among the junior doctors in East Midlands, UK.

\section{MATERIALS AND METHODS}

This was a cross-sectional study performed between 28 June 2020 and 29 September 2020 . A 26-item questionnaire-based online survey was distributed to the junior doctors / house 
medRxiv preprint doi: https://doi.org/10.1101/2021.03.04.21252895; this version posted May 27, 2021. The copyright holder for this preprint (which was not certified by peer review) is the author/funder, who has granted medRxiv a license to display the preprint in perpetuity. It is made available under a CC-BY-NC 4.0 International license.

officers ( $<3$ years of medical practice) who were working in the East Midlands, UK. The questionnaire was composed of 26 questions, which evaluated the background and ophthalmology training of participants (6 items), knowledge of corneal (and tissue) donation (13 items) and the new opt-out system (2 items), views and experience in obtaining consent for corneal donation (4 items), and views on certifying death (1 item). The detail of the questionnaire is provided in Supplementary Figure 1. The questionnaire was devised based on the previous studies ${ }^{7,8}$ and the suitability and contraindications to corneal donation set by the guideline of the National Health Service Blood and Transplant (NHSBT;

https://www.transfusionguidelines.org/red-book/chapter-21-tissue-banking-tissue-retrievaland-processing/21-2-retrieval). Ethics approval was obtained from the Research Ethic Committee at the University of Nottingham, UK, prior to the conduct of study (Reference: FMHS 45-0720). The study was conducted in accordance with the tenets of the Declaration of Helsinki.

\section{RESULTS}

\section{Characteristics and experience of junior doctors}

Of all 340 junior doctors, 143 survey responses were received (42.1\%, response rate). The amount of previous undergraduate teaching on ophthalmology was $11.4 \pm 12.1$ days (range, 0-90 days; Table 1). Only 24 (16.8\%) junior doctors had undergone an ophthalmology training rotation during their Foundation Year training. The mean number of discussions of corneal donation held between the junior doctors and the potential donors' family members was $0.2 \pm 0.6$ (range, $0-4$ ), with the majority $(124,86.7 \%)$ of junior doctors having never held any discussion on corneal donation. However, 100 (69.9\%) of them felt that it was important to know how to obtain consent for corneal donation as a junior doctor but 119 (83.2\%) were uncomfortable in discussing corneal donation with the family members. 
medRxiv preprint doi: https://doi.org/10.1101/2021.03.04.21252895; this version posted May 27, 2021. The copyright holder for this preprint

(which was not certified by peer review) is the author/funder, who has granted medRxiv a license to display the preprint in perpetuity.

Table 1. Background of ophthalmology training and intent for corneal donation among the junior doctors.

\begin{tabular}{l}
\hline Parameters \\
\hline Level of training \\
Foundation Year 1 \\
Foundation Year 2 \\
Other
\end{tabular}

\section{Total $\mathbf{N}=143$}

$\mathrm{N}(\%)$

Amount of undergraduate ophthalmology teaching, days

0

1-7

8-14

$15-30$

$83(58.0)$

$50(35.0)$

$10(7.0)$

$>30$

$55(38.5)$

$65(45.5)$

$11(7.7)$

$7(4.9)$

Any ophthalmology rotation during Foundation Year (FY) training

Yes

No

Willingness to donate corneas

Yes

$87(60.8)$

No

$15(10.5)$

Uncertain

Number of previous discussions with potential donors or their family members on corneal donation

0

$1-2$

$124(86.7)$

$>2$

$17(11.9)$

$2(1.4)$

Felt that it was important to know how to obtain consent for corneal donation

Yes

No

$100(69.9)$

Maybe

Comfortable in discussing corneal donation

Very or somewhat comfortable

Neutral

$24(16.8)$

Very or somewhat uncomfortable

$74(51.7)$

Felt that undergraduate teaching was sufficient for discussing corneal donation

Yes

No

Sources of corneal donation information

Undergraduate teaching

$43(30.1)$

FY training

Internet

$71(49.7)$

Social media

$23(16.1)$

Health professionals

$32(22.4)$

Friends

$21(14.7)$ 
medRxiv preprint doi: https://doi.org/10.1101/2021.03.04.21252895; this version posted May 27 , 2021. The copyright holder for this preprint (which was not certified by peer review) is the author/funder, who has granted medRxiv a license to display the preprint in perpetuity.

\section{Knowledge of corneal (and tissue) donation and the new opt-out system}

The knowledge of corneal (and tissue) donation, including 3 items on ocular conditions and 10 items on general health or systemic conditions, among the junior doctors is summarised in Figure 1. Overall, the mean correct response rate was $31.9 \pm 20.4 \%$ (range, $0-76.9 \%$ ).

Only 28 (19.6\%) and 51 (35.7\%) junior doctors were correct about the 24-hour death-toenucleation and the ideal 6-hour death-to-body chilling time limit (for tissue donation). Only $40(28.0 \%)$ junior doctors were correct that there was no age limit for corneal donation. The knowledge of corneal donation was not influenced by the level of the junior doctors $(p=0.36)$, amount of undergraduate ophthalmology teaching $(p=0.19)$, previous ophthalmology rotation $(p=0.71)$, previous experience in discussing corneal donation $(p=0.73)$, and willingness to donate their own corneas $(p=0.16$; Supplementary Table 1$)$. The majority $(116,81.1 \%)$ of junior doctors would consider certifying a death on the ward quicker if they knew it could compromise the quality of corneas.

The majority $(103,72 \%)$ of junior doctors were aware of the recently introduced opt-out system in England. In the event of family members refusing to donate organs/tissues of the deceased patient, only 56 (39.2\%) junior doctors correctly stated that the organs and tissues cannot be retrieved.

\section{DISCUSSION}

To the best of our knowledge, this represents the first study examining the views and knowledge of corneal donation and the new opt-out system among junior doctors in the UK. Currently, in the UK, consent for corneal donation is primarily obtained by a team of welltrained, specialised nurses from the National Referral Centre (NRC) embedded within the NHSBT. This process takes place as soon as the death has been certified and notified to the NRC. Although junior doctors working at frontline services are not expected to obtain consent for corneal donation in the UK, they are the key multi-disciplinary members who 
medRxiv preprint doi: https://doi.org/10.1101/2021.03.04.21252895; this version posted May 27, 2021. The copyright holder for this preprint (which was not certified by peer review) is the author/funder, who has granted medRxiv a license to display the preprint in perpetuity. It is made available under a CC-BY-NC 4.0 International license .

have daily contact with the patients and potential organ/tissue donors and may therefore play an important role in the process of organ and tissue donations (see Supplementary Figure 2 for an example of the eye donation process in England). In addition, junior doctors are usually the key members in discussing the advance directives such as "Do not attempt cardiopulmonary resuscitation (DNACPR)" with the family members. Therefore a successful relationship of trust has already been built throughout the process of care, which could improve the conversion rate of corneal donation. ${ }^{9}$ Our study showed that around $13 \%$ of the junior doctors had been involved in the discussion of corneal donation with the family members, and this figure is likely to increase under the new opt-out system. Studies have shown that prior knowledge of corneal donation serves as an important factor in influencing the willingness of donating the corneas. ${ }^{10}$ Therefore, if an earlier discussion on corneal donation can be held between the junior doctors and potential donors' family members, the chances of corneal donation can be potentially improved when it comes to the stage of formal consenting by the NRC.

The NHSBT has set a 24-hour cut-off interval between death and retrieval of donor corneas and the body should preferably be refrigerated (https://www.transfusionguidelines.org/redbook/chapter-21-tissue-banking-tissue-retrieval-and-processing/21-2-retrieval). For other tissues, it is also recommended that the body should be refrigerated within an ideal window of 6 hours after death and the procurement of tissues needs to be completed within 24-48 hours. If not refrigerated, the tissues (excluding corneas) will then need to be retrieved within 12 hours of death due to the risk of tissue contamination. As the responsibility of certifying death often rests on the junior doctors, they play a vital role in determining the promptness in death certification, body refrigeration and subsequent eye retrieval, which has an important influence on the quality of the donor corneas. ${ }^{11,12}$

We observed that the amount of ophthalmology teaching provided during the undergraduate training was low. Therefore, it would be difficult or impractical to incorporate teaching on 
medRxiv preprint doi: https://doi.org/10.1101/2021.03.04.21252895; this version posted May 27, 2021. The copyright holder for this preprint (which was not certified by peer review) is the author/funder, who has granted medRxiv a license to display the preprint in perpetuity. It is made available under a CC-BY-NC 4.0 International license .

corneal donation in undergraduate training. Moreover, depending on the clinical rotation during the Foundation Year programme, many doctors may never be involved in the discussion of organ/tissue donations. In view of these issues, training on corneal (and tissue) donation may be best targeted during postgraduate training, particularly in training rotations that usually deal with end-of-life care such as intensive care and oncology specialties. A potential strategy could be to incorporate a short mandatory induction training course at the start of these training rotations to improve the knowledge of corneal and tissue donation. As discussion of corneal and tissue donation with the family is relatively low among the junior doctors, we suggest that training of junior doctors should focus more on raising the awareness of the time limits and earlier death certification and notification of the relevant eye donation/retrieval personnel, instead of improving the knowledge of the actual contraindications of corneal and tissue donation.

Studies have shown that an opt-out system does not always translate to improved organ/tissue donation rate. ${ }^{13}$ One of the potential barriers could be attributed to the misperception of the opt-out system as shown in our survey. We observed that $61 \%$ of the junior doctors were incorrect about the fact that donation can proceed in the event of family refusal under the new opt-out system. Such misperception may affect the rate of donation as the junior doctors would not take the initiatives to discuss about organ/tissue donations, assuming that presumed consent automatically translates to donation.

One of the study limitations was that this survey only included the junior doctors working in the East Midlands, UK. However, these junior doctors were likely to have graduated from different medical schools, as reflected by the difference in the amount of undergraduate ophthalmology training received. It would be useful to survey the junior doctors working in other regions of the UK to enable a more generalised assessment of the knowledge and postgraduate training in corneal donation in the future. The reason we chose to survey junior doctors because they are the group of doctors who are most commonly involved in the initial 
medRxiv preprint doi: https://doi.org/10.1101/2021.03.04.21252895; this version posted May 27, 2021. The copyright holder for this preprint (which was not certified by peer review) is the author/funder, who has granted medRxiv a license to display the preprint in perpetuity. It is made available under a CC-BY-NC 4.0 International license.

process of death certification, which triggers the notification of the eye donation team.

Secondly, the accuracy of the collected data relied on the honesty of the participants as this study was performed as an online survey. However, the relatively low number of correct responses provided by the respondents suggests that these were likely the true responses of the junior doctors.

In conclusion, our survey highlights the lack of knowledge of corneal donation and the new opt-out system among the junior doctors in the UK. Given the persistent shortage of donor corneas and the recent impact of COVID-19 on corneal donation, further targeted postgraduate training, particularly in specialties that deal with end-of-life care, could potentially enhance the corneal donation rate in the future.

\section{CONTRIBUTORSHIP STATEMENT}

Study conceptualisation and design: BP and DSJT

Data collection: BP, OATL, PF, NEN, and all collaborators.

Date interpretation: BP, EB, DGS, HSD and DSJT

Manuscript drafting: BP and DSJT

Critical revision of the manuscript: OATL, PF, NEN, EB, DGS and HSG.

Final approval of the manuscript: All authors.

Overall supervision of the study: DSJT

Funding: DSJT acknowledges support from the Medical Research Council / Fight for Sight Clinical Research Fellowship (MR/T001674/1), and the Fight for Sight / John Lee, Royal College of Ophthalmologists Primer Fellowship (24CO4).

Competing interests: None

Acknowledgement: None 
medRxiv preprint doi: https://doi.org/10.1101/2021.03.04.21252895; this version posted May 27, 2021. The copyright holder for this preprint (which was not certified by peer review) is the author/funder, who has granted medRxiv a license to display the preprint in perpetuity.

\section{REFERENCES}

1. Ting DSJ, Ho CS, Deshmukh R, Said DG, Dua HS. Infectious keratitis: An update on epidemiology, causative microorganisms, risk factors, and antimicrobial resistance. Eye (Lond). 2021;35(4):1084-1101.

2. Tan DT, Dart JK, Holland EJ, Kinoshita S. Corneal transplantation. Lancet. 2012;379(9827):1749-61.

3. Ting DS, Potts J, Jones M, Lawther T, Armitage WJ, Figueiredo FC. Impact of telephone consent and potential for eye donation in the UK: the Newcastle Eye Centre study. Eye (Lond). 2016;30(3):342-8.

4. Ting DS, Potts J, Jones M, Lawther T, Armitage WJ, Figueiredo FC. Changing trend in the utilisation rate of donated corneas for keratoplasty in the UK: The North East England Study. Eye (Lond). 2016;30(11):1475-80.

5. Gupta N, Vashist P, Ganger A, Tandon R, Gupta SK. Eye donation and eye banking in India. Natl Med J India. 2018;31(5):283-6.

6. Ting DS, Sau CY, Srinivasan S, Ramaesh K, Mantry S, Roberts F. Changing trends in keratoplasty in the West of Scotland: a 10-year review. $\mathrm{Br} \mathrm{J}$ Ophthalmol 2012;96(3):405-8.

7. Hakeem AR, Rave R, Prasad KR, Menon KV, Lewington A, Fernando B, et al. An imperative need to change organ donation and transplant curriculum results of a nationwide United Kindom junnior doctor survey. Transplantation 2015;99(4):771-85.

8. Eze BI, Okoye O, Eze JN. Knolwedge and attitudes regarding eye donation and corneal transplant: medical versus nonmedical university studnes in a developing country in Africa. Exp Clin Transplannt. 2014;12(5):454-61.

9. Ladin K. Organ Donation as a Collective Action Problem: Ethical Considerations and Implications for Practice. AMA J Ethics. 2016;18(2):156-62.

10. Lawlor M, Kerridge I, Ankeny R, Dobbins TA, Billson F. Specific unwillingness to donate eyes: the impact of disfigurement, knowledge and procurement on corneal donation. Am J Transplant. 2010;10(3):657-63. 
medRxiv preprint doi: https://doi.org/10.1101/2021.03.04.21252895; this version posted May 27, 2021. The copyright holder for this preprint (which was not certified by peer review) is the author/funder, who has granted medRxiv a license to display the preprint in perpetuity. It is made available under a CC-BY-NC 4.0 International license.

11. Munir WM, Brown $\mathrm{CH}$, Munir SZ, Hoover CK. Effect of Body Refrigeration Time on Cornea Donor Tissue. Cornea. 2021; doi: 10.1097/ICO.0000000000002665.

12. Patel D, Tandon R, Ganger A, Vij A, Lalwani S, Kumar A. Study of death to preservation time and its impact on utilisation of donor corneas. Trop Doct. 2017;47(4):365-70.

13. Rithalia A, McDaid C, Suekarran S, Myers L, Sowden A. Impact of presumed consent for organ donation on donation rates: a systematic review. BMJ. 2009;338:a3162.

\section{FIGURES AND SUPPLEMENTARY DOCUMENTS}

Knowledge of cornea and tissue donation among the junior doctors

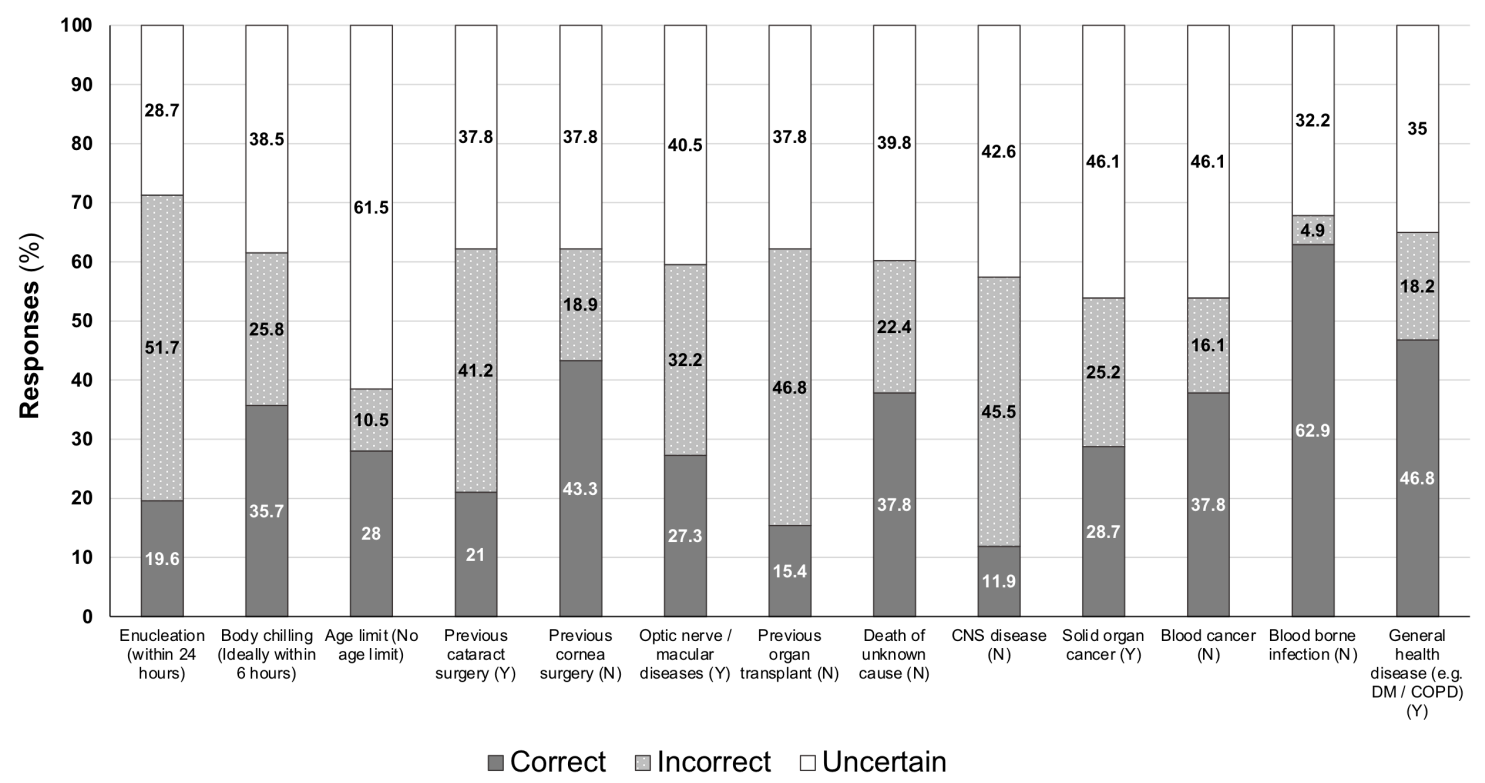

Figure 1. A summary of the knowledge of corneal and tissue donation amongst junior doctors in the UK. Columns 1-3 and 7-13 are related to general health or systemic conditions whereas columns 4-6 are related to ocular conditions. For each question, the correct response is provided in bracket $(Y=$ Suitable for donation; $N=$ Not suitable for donation). The answers provided by the respondents are divided into either correct, incorrect or uncertain responses. CNS = Central nervous system; $\mathrm{DM}=$ Diabetes mellitus; $\mathrm{COPD}=$ Chronic obstructive pulmonary disease 
medRxiv preprint doi: https://doi.org/10.1101/2021.03.04.21252895; this version posted May 27, 2021. The copyright holder for this preprint

(which was not certified by peer review) is the author/funder, who has granted medRxiv a license to display the preprint in perpetuity.

It is made available under a CC-BY-NC 4.0 International license .

Supplementary Table 1. Factors that may influence the knowledge of corneal and tissue donation among the junior doctors in the UK. For analytic purpose, junior doctors were divided into two groups based on the number of correct answers (a total of 13 questions). Group A refers to those with less than $50 \%$ correct response (0-6 correct answers) and Group B refers to those with more than $50 \%$ correct response (7-13 correct answers).

\begin{tabular}{|c|c|c|c|}
\hline Parameters & $\begin{array}{c}\text { Group A } \\
\text { Total N = 117; } \\
\text { N (\%) }\end{array}$ & $\begin{array}{c}\text { Group B } \\
\text { Total N = 26; } \\
\text { N (\%) }\end{array}$ & P-value \\
\hline Level of junior doctors & & & 0.36 \\
\hline FY1 & 70 & 13 & \\
\hline FY2 or higher & 47 & 13 & \\
\hline $\begin{array}{l}\text { Number of UG ophthalmology } \\
\text { teaching, days }\end{array}$ & $10.8 \pm 11.3$ & $14.3 \pm 15.2$ & 0.19 \\
\hline $\begin{array}{l}\text { Previous ophthalmology } \\
\text { training rotation during FYP }\end{array}$ & & & 0.71 \\
\hline Yes & $19(16.2)$ & $5(19.2)$ & \\
\hline No & $98(83.8)$ & $21(80.8)$ & \\
\hline $\begin{array}{l}\text { Previous discussion of corneal } \\
\text { donation }\end{array}$ & & & 0.73 \\
\hline Yes & $15(12.8)$ & $4(15.4)$ & \\
\hline No & $102(87.2)$ & $22(84.6)$ & \\
\hline $\begin{array}{l}\text { Willingness to donate own } \\
\text { corneas }\end{array}$ & & & 0.16 \\
\hline Yes & $68(58.1)$ & $19(73.1)$ & \\
\hline No & $49(41.9)$ & $7(26.9)$ & \\
\hline
\end{tabular}

UG = Undergraduate; FYP = Foundation year programme

Continuous values are presented in mean \pm standard deviation. 
medRxiv preprint doi: https://doi.org/10.1101/2021.03.04.21252895; this version posted May 27, 2021. The copyright holder for this preprint

Supplementary Figure 1. List of questions asked in the survey to evaluate the knowledge of cornea (and tissue) donation and the new opt-out system among junior doctors in the UK.

Q1. What is the level of training? (choose from the dropdown list)?

Q2. Have you done any ophthalmology rotations during your foundation year training? Yes / No

Q3. How much ophthalmology teaching did you get during your undergraduate medical training?

Q4. Are you aware that the new UK opt out organ donation system was introduced on $20^{\text {th }}$ May $2020 ? \quad$ Yes / No

Q5. In an opt out system, everyone is considered to be a potential donor unless they have officially stated the opposite. In the event of family members refuse to donate the organs and tissues (including corneas) of the deceased patient, can the donation still be carried out?

Yes / No / Not sure

Q6. How many times have you discussed about cornea donation with potential donors or their family members?

Q7. How comfortable are you with talking about cornea donation with families after death of their relative?

Very uncomfortable / Somewhat uncomfortable / Neither uncomfortable nor comfortable / Somewhat comfortable / Very comfortable

Q8. Do you feel that medical schools have provided sufficient training for you to discuss about corneal donation with family members or patients?

Yes / No

Q9. As a foundation doctor, do you think it is important for you to know how to consent patients or their family members for corneal donation?

Yes / No / Not sure

Q10. What is the maximum time limit for the eyes or corneas to be retrieved after a donor's death?

Within 6 hours / Within 12 hours / Within 24 hours / Within 48 hours / Not sure 
medRxiv preprint doi: https://doi.org/10.1101/2021.03.04.21252895; this version posted May 27, 2021. The copyright holder for this preprint

Q11. What is the ideal time window that a deceased body should be chilled (for tissue donation)?

Within 6 hours / Within 12 hours / Within 24 hours / Within 48 hours / Not sure

Q12. Is there any lower or upper age limit for corneal donation?

Yes / No / Not sure

Q13. Which of the following is a contraindication for corneal donation? (Options include "Yes / No / Not sure" for each sub-question)

Q13a. Previous human organ tissue transplant

Q13b. Death from an unknown cause

Q13c. Central nervous system (CNS) disease such as dementia and Parkinson's disease

Q13d. Solid organ cancer (e.g. lung cancer, breast cancer, etc.)

Q13e. Haematological cancer (e.g. leukemia, lymphoma and metastatic malignant melanoma)

Q13f. Blood borne disease (e.g. HIV, hepatitis B, C, E)

Q13g. Previous cataract surgery

Q13h. Previous corneal refractive surgery (e.g. LASIK, PRK)

Q13i. Ocular diseases such as glaucoma or age-related macular degeneration

Q13j. Chronic disease such as diabetes or COPD

Q14. If the delay in certification of a patient's death and admission to the mortuary can potentially compromise the quality of donor corneas, would you consider certifying a death on the ward quicker to avoid any delay?

Yes / No / Not sure

Q15. Where have you got information about corneal donation? (you can choose more than 1 option)

Undergraduate teaching

FY training

Internet Family Friends Publicity campaigns Health professionals

Social Media TV Newspaper Radio

Q16. Do you or any of your family members have or had any corneal diseases that required corneal transplantation? Yes / No

Q17. Are you willing to donate your corneas?

Yes / No / Not sure (please provide reasons if No or Not sure is selected) 


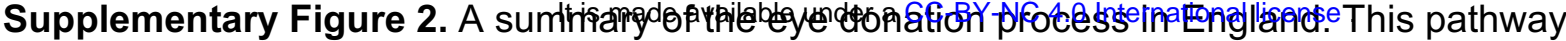

highlights the important role of junior doctors, who are often the first point of contact in certifying hospital death and influencing the timeliness of body refrigeration in mortuary and notification of the eye / tissue donation team.

\section{Tissue and Eye Donation Process In England}

Bereavement Team is informed of patient death

Tissue and Eye donation team refers to the NRC, who telephones the family to go through a further medical assessment and consent.

OR

The NRC telephones the family to go through a further medical assessment and consent.

Family is contacted by either the Tissue and Eye donor team OR the NRC and offered information about the possibility of donation.

Do the family want to proceed?
Porters are contacted to transfer patient to the mortuary

Automatic/Direct referral is sent to the

National Referral Centre (NRC) from the hospital (if no local donation team available)

Are any contraindications identified?

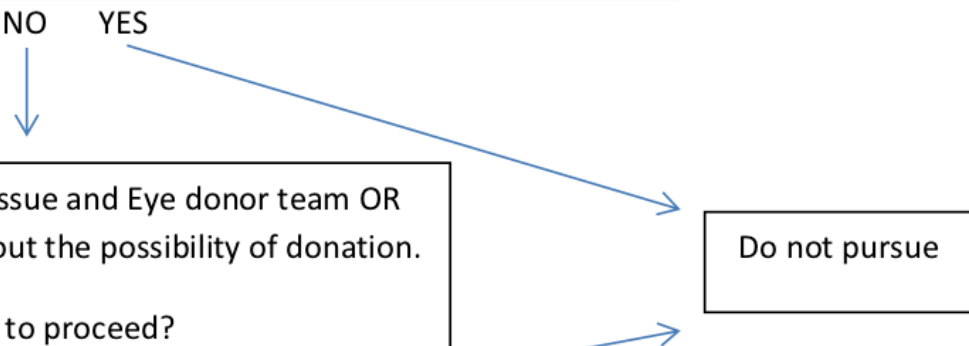

NO

$\downarrow$

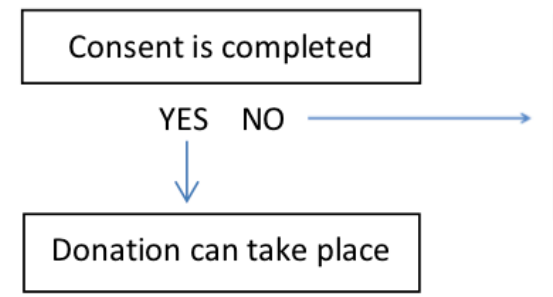

Patient is deferred during consent process, unable to proceed with donation 